\title{
Laxative effects of Salecan on normal and two models of experimental constipated mice
}

\author{
Mengyi Zhou, Ping Jia, Jinping Chen, Aihui Xiu, Yue Zhao, Yibei Zhan, Peng Chen and Jianfa Zhang*
}

\begin{abstract}
Background: Constipation is one of the most common gastrointestinal complaints with a highly prevalent and often chronic functional gastrointestinal disorder affecting health-related quality of life. The aim of the present study was to evaluate the effects of Salecan on fecal output and small intestinal transit in normal and two models of drug-induced constipation mice.

Methods: ICR mice were administrated intragastrically (i.g.) by gavage with 100, 200 and $300 \mathrm{mg} / \mathrm{kg}$ body weight (BW) of Salecan while the control mice were received saline. The constipated mice were induced by two types of drugs, loperamide (5 mg/kg BW, i.g.) and clonidine (200 $\mu \mathrm{g} / \mathrm{kg}$ BW, i.g.), after Salecan treatment while the control mice were received saline. Number, weight and water content of feces were subsequently measured. Small intestinal transit was monitored by phenol red marker meal.

Results: Salecan (300 mg/kg BW) significantly increased the number and weight of feces in normal mice. In two models of drug-induced constipation, Salecan dose-dependently restored the fecal number and fecal weight. The water content of feces was markedly affected by loperamide, but not by clonidine. Treatment with Salecan significantly raised the fecal water content in loperamide-induced constipation mice. Moreover, Salecan markedly stimulated the small intestinal transit in both loperamide- and clonidine-induced constipation model mice.
\end{abstract}

Conclusions: These results suggest that Salecan has a potential to be used as a hydrophilic laxative for constipation.

Keywords: Salecan, Constipation, Intestinal motility, Loperamide, Clonidine

\section{Background}

Constipation, defined as infrequent or difficult evacuation of feces [1], is a worldwide functional gastrointestinal disorder. A systematic review recorded prevalence rates in six different population groups from Asia ranging widely from $11.6 \%$ to $29.6 \%$ [2]. In general, constipation appears to be more common in the elderly, women, nonwhites, and persons in lower socio-economic and education classes [3]. Constipation also significantly impacts health-related quality of life in constipated people [4]. A primary mechanism for slow-transit constipation is a failure of peristalsis to move luminal contents through the colon results in more time for bacterial degradation of stool solids and more time for salt and water absorption, thus reducing stool frequency and stool weight dramatically [5]. Medical therapy for constipation contains traditional laxatives and agents.

\footnotetext{
* Correspondence: jfzhang@mail.njust.edu.cn

Center for Molecular Metabolism, Nanjing University of Science \&

Technology, 200 Xiaolingwei Street, Nanjing 210094, China
}

The former can induce defecation or modify stool consistency to make defecation easier, while the latter targets presumed defects in colonic neuromuscular function $[5,6]$. Although a common problem, the treatment of constipation has been far from satisfactory [7].

Beta-glucans, naturally occurring polysaccharides with poly-branched beta- $(1 \rightarrow 3)$-D-glucans or beta- $(1 \rightarrow 6)$-Dglucose side chains, are a major component of the bran of cereal plant and the cell wall of bacteria and fungi $[8,9]$. A number of studies demonstrate beta-glucans may be beneficial in gastrointestinal disease prevention and health promotion, including reduction of cholesterol absorption and bile acids excretion [10], fermentation by intestinal bacteria that yields short chain fatty acids [11], resistance to enteric bacterial and viral infections [12,13], stimulation autochthonous Lactobacillus populations in the colon [14], and prevention of colorectal cancer by effecting immune and cancer cells [15]. In addition, early observers suggest that a decreasing prevalence of constipation is

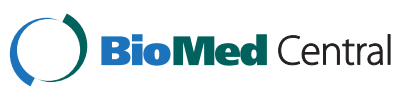


associated with an increasing dietary fiber intake, depending on their ability to avoid digestion and absorption in small intestine and to escape bacterial metabolism in colon [16]. Cummings [17] has tabulated the efficacy of different fibers in terms of increased fecal weight per gram of administered fiber, including wheat bran, psyllium, cellulose, oats, corn, legumes, and pectin. Psyllium polysaccharide from Plantago ovate is approved by the FDA for its proven laxative effects as available fiber supplements [18,19].

Salecan, produced by Agrobacterium sp. ZX09, is a novel high molecular, water-soluble extracellular polysaccharide, and its structure is proven to consist of the following repeating unit: $\rightarrow 3)-\beta-D-G l c p-(1 \rightarrow 3)-[\quad \beta$-D-Glcp- $(1 \rightarrow 3)-\beta$ D-Glcp- $(1 \rightarrow 3)] 3-\alpha-D-G l c p-(1 \rightarrow 3)-\alpha-D-G l c p-(1 \rightarrow[20]$. As a new beta-glucan with special molecular structure, its safety has been demonstrated in the acute and subchronic experiment [21]. Supplementation with Salecan reduced adiposity and improved glucose tolerance in high-fat dietfed mice through disturbing bile acid-promoted emulsification in intestine [22]. Its rheology study indicates that Salecan has a non-Newtonian viscosity behavior, and could be utilized in the food industry [23]. In the present study, we estimated the laxative effects of Salecan on fecal output and small intestinal transit in normal and two models of drug-induced constipation mice. Our results suggest that Salecan may be used as a hydrophilic laxative for constipation.

\section{Methods}

\section{Salecan}

Salecan was prepared according to previous methods [20]. Briefly, Agrobacterium sp. ZX09 used in this study was isolated from a soil sample from the ocean coast of Shandong, China. Cultures were maintained on $\mathrm{Htm}$ agar containing $\mathrm{NaH}_{2} \mathrm{PO}_{4}(1 \mathrm{~g}), \mathrm{KNO}_{3}$ (3 g), $\mathrm{CaCl}_{2}$ (0.07 g), $\mathrm{MgCl}_{2}$ (0.2 g), $\mathrm{FeSO}_{4} \cdot 7 \mathrm{H}_{2} \mathrm{O}$ (0.0125 g), $\mathrm{MnSO}_{4}$ (0.003 g), $\mathrm{ZnCl}_{2}(0.0075 \mathrm{~g})$, sucrose (20 g), agar (9 g) and $\mathrm{H}_{2} \mathrm{O}(1000 \mathrm{ml}), \mathrm{pH} 7.2$. A colony of the strain ZX09 was inoculated into a $250 \mathrm{ml}$ flask containing $50 \mathrm{ml}$ medium consisting of $2 \%$ sucrose and mineral salt solution. The inoculated preparation was incubated at $28^{\circ} \mathrm{C}$ on a rotary shaker at $220 \mathrm{rpm}$ for $24 \mathrm{~h}$. A $0.5 \mathrm{ml}$ portion was transferred to a $250 \mathrm{ml}$ flask containing $50 \mathrm{ml}$ fermentation medium. Fermentation was performed on a rotary shaker at $220 \mathrm{rpm}$ for $48 \mathrm{~h}$. The culture broth was diluted more than 3 times with de-ionized water and centrifuged at $12000 \times g$ for $30 \mathrm{~min}$ to separate cells from the supernatant. The supernatant was added to two volumes of $95 \%$ ethanol. Productivity of Salecan was expressed in terms of the weight after ethanol precipitation collected by centrifugation at $6000 \times g$ for 15 min and dried under reduced pressure. The chemical composition, solution viscosity and water holding capacity (WHC) of Salecan were shown in Table 1.
Table 1 The chemical composition and physical characteristics of Salecan

\begin{tabular}{cc}
\hline Characteristic & Value \\
\hline Composition & \\
Sugar & $77.13 \%$ \\
Protein & $6.2 \%$ \\
Moisture & $5.2 \%$ \\
Ash & $10.28 \%$ \\
Viscosity & \\
$0.4 \mathrm{~g} / 60 \mathrm{ml} \mathrm{H} \mathrm{H}_{2} \mathrm{O}$ & $3260 \mathrm{mPa} \cdot \mathrm{s}$ \\
$0.8 \mathrm{~g} / 60 \mathrm{ml} \mathrm{H} \mathrm{H}_{2} \mathrm{O}$ & $7850 \mathrm{mPa} \cdot \mathrm{s}$ \\
$1.2 \mathrm{~g} / 60 \mathrm{ml} \mathrm{H} \mathrm{O}$ & $9500 \mathrm{mPa} \cdot \mathrm{s}$ \\
Water holding capacity & $9.7 \mathrm{~g} / \mathrm{g} \mathrm{H} \mathrm{O}_{2}$ \\
\hline
\end{tabular}

\section{Animals}

Male ICR mice (8 weeks old) were purchased from SLAC (Shanghai Laboratory Animal Center, Shanghai). All animals, used after 1 week of acclimation (temperature $22 \pm$ $2^{\circ} \mathrm{C} ; 12 / 12 \mathrm{~h}$ light/dark cycles), had free access to standard lab chow and water. All animal procedures were approved by the Institutional Animal Care and Use Committee of Nanjing University of Science and Technology.

\section{Fecal parameters measurements in normal mice}

Mice, given food and water $a d$ lib, were randomly divided into four groups ( $\mathrm{n}=5$ in each group): control and Salecan (three groups of different dosage). After either Salecan (100, 200 and $300 \mathrm{mg} / \mathrm{kg}$ BW, doses based on Maeda et al. [24] and Shan et al. [25]) or saline was administered (i.g.), the animals were immediately placed in clean transparent cages individually and allowed access to their standard lab chow and top water ad libitum. Then, feces for each mouse were collected, counted and weighted at 0-8 h period. The number and weight of feces were expressed in terms of the total number and wet weight per mouse.

\section{Fecal parameters measurements in two types of constipation model mice}

The number and weight of feces for each mouse in loperamide- and clonidine-induced constipation model mice were measured as the method of Kakino et al. $[26,27]$. The mice, given food and water ad lib, were administered (i.g.) saline or Salecan at 100, 200 or $300 \mathrm{mg} /$ $\mathrm{kg} \mathrm{BW}$, and then administered loperamide $(5 \mathrm{mg} / \mathrm{kg} \mathrm{BW}$, dissolved in $1 \%$ Tween $80 /$ saline, i.g.) at $1 \mathrm{~h}$ after or clonidine $(200 \mu \mathrm{g} / \mathrm{kg} \mathrm{BW}$, dissolved in saline, i.g.) at $45 \mathrm{~min}$ after Salecan treatment. Then, the experimental processes were in accordance with Section 2.3. After weighted, the wet feces for each mouse were dried at $105^{\circ} \mathrm{C}$ for $48 \mathrm{~h}$. The water content of feces was calculated as:fecal water content $(\%)=($ feces weight before dried - feces weight after dried)/feces weight before dried $\times 100$. 


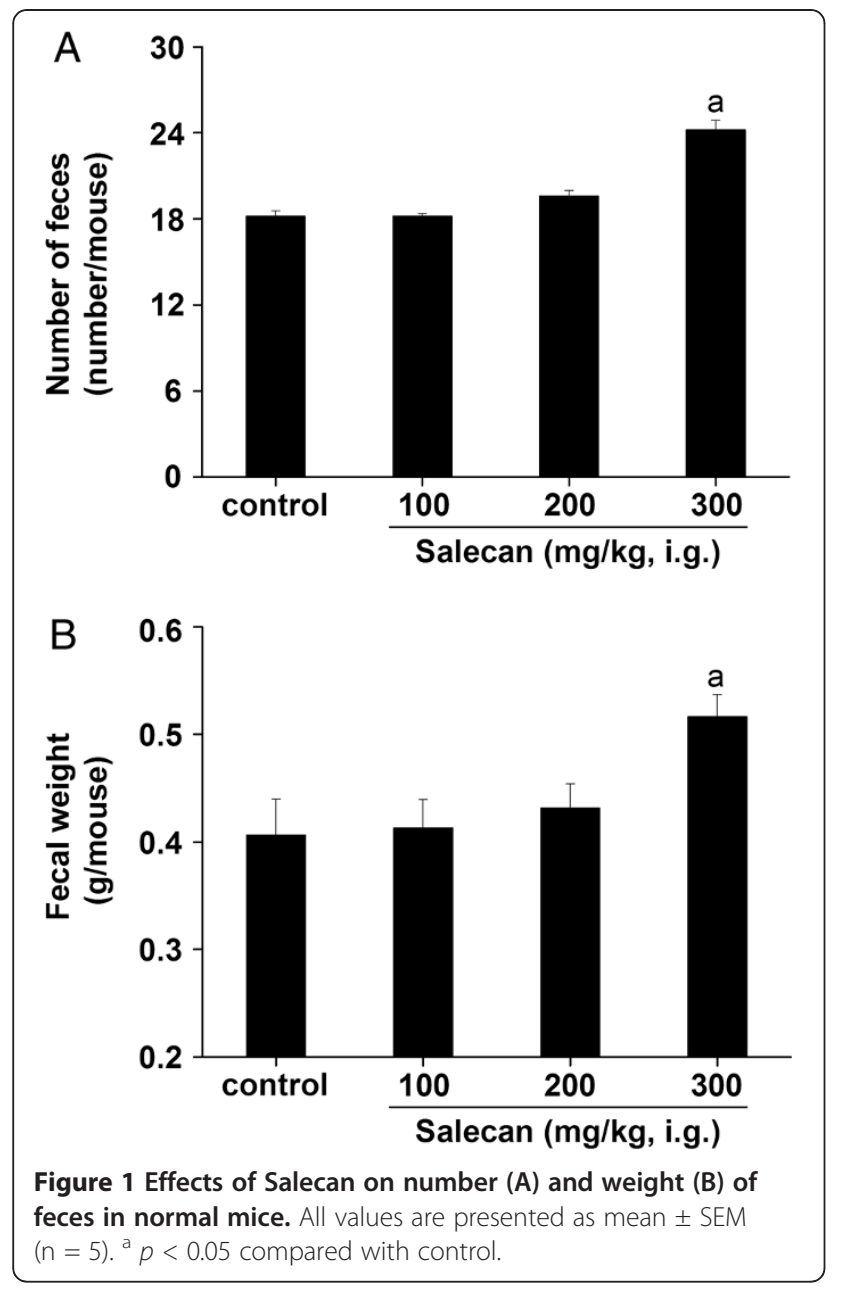

Determination of small intestinal transit

Small intestinal transit (SIT) was determined using a phenol red marker meal (0.5\% phenol red indicator in $1.5 \%$ methylcellulose; $10 \mathrm{ml} / \mathrm{kg} \mathrm{BW}$, i.g.), followed the previous studies [26]. Administering of three doses of Salecan and two models of constipation were in accordance with Section 2.4. After fasted for $14 \mathrm{~h}$ with water ad libitum, all mice were administered by i.g. with either Salecan or saline at $1 \mathrm{~h}$ before loperamide or at $45 \mathrm{~min}$ before clonidine. After $30 \mathrm{~min}$, a phenol red marker meal was administered to experimental mice. After $20 \mathrm{~min}$, the mice were sacrificed by cervical dislocation under anesthesia with diethyl ether. The small intestine from the pylorus to the blind intestine was carefully removed. The SIT (\%) for each animal was calculated as: distance traveled by phenol red marker meal/total length of the small intestine $\times 100$.

\section{Statistics}

All data are expressed as mean \pm SEM. Differences between groups were analyzed by one-way analysis of variance (ANOVA) followed by the Tukey test. Differences between means were considered statistically significant at $p<0.05$.

\section{Results}

Increased fecal output in normal mice treated with Salecan The effects of Salecan on number and weight of feces in normal mice were shown in Figure 1. Compared with the control, treatment with Salecan $(300 \mathrm{mg} / \mathrm{kg}$ BW)

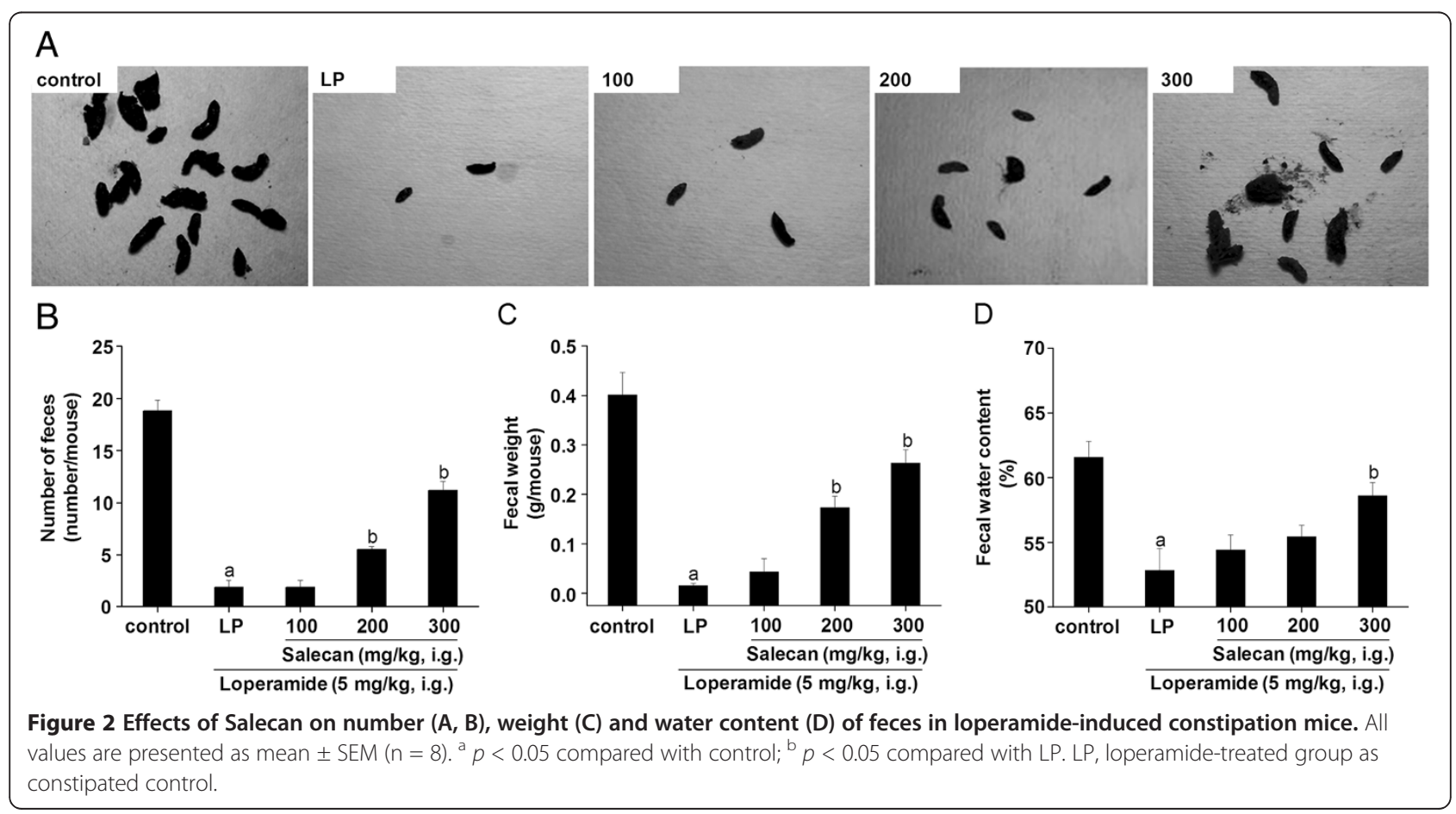




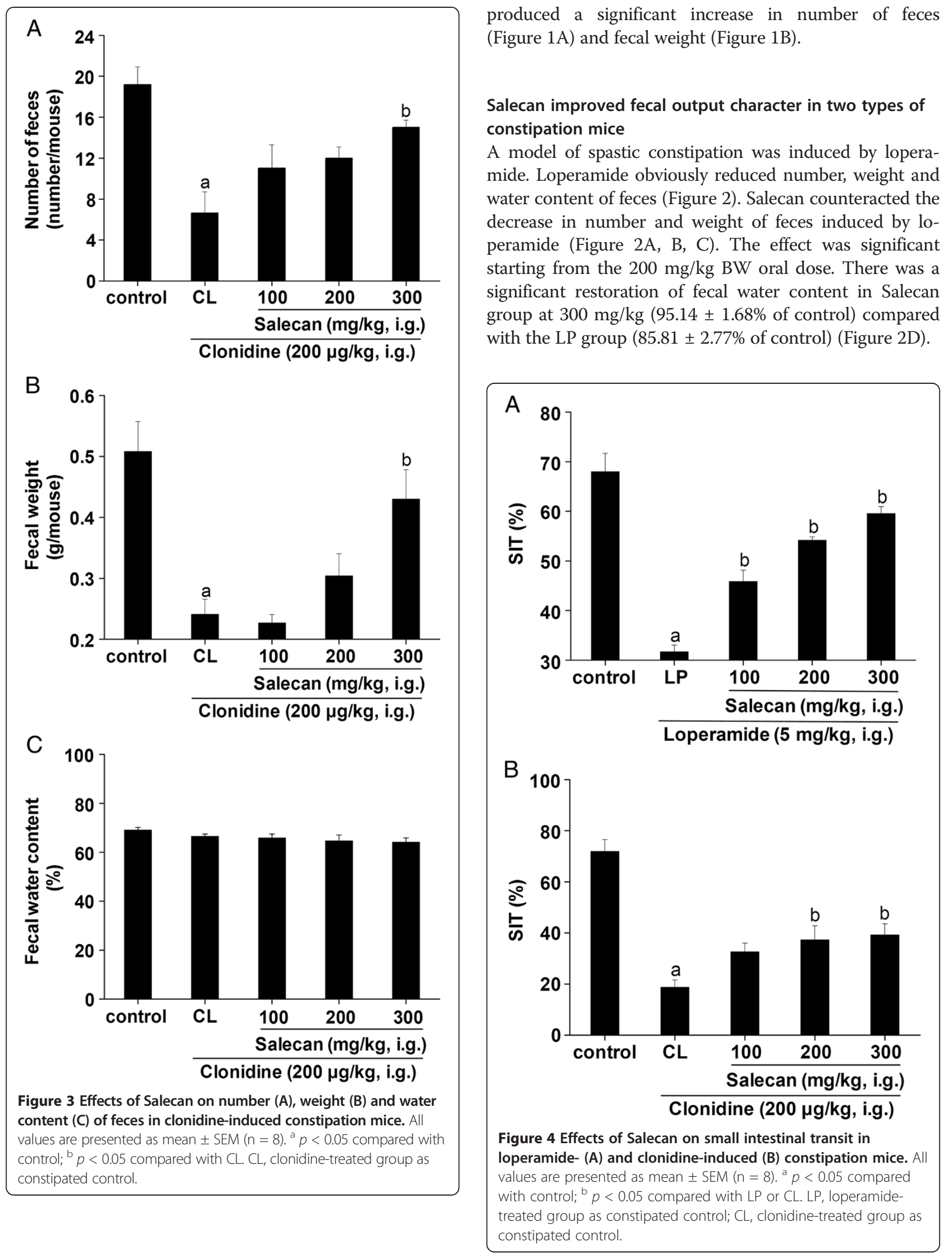


A model of atonic constipation was induced by clonidine. Clonidine significantly reduced the fecal number from $\sim 19$ to $\sim 7$ and fecal weight from $\sim 0.5 \mathrm{~g}$ to $\sim 0.24 \mathrm{~g}$ (Figure 3A, B). Salecan at a dose of $300 \mathrm{mg} / \mathrm{kg}$ obviously increased the fecal number and fecal weight to 15 and $\sim 0.43$ g, respectively (Figure $3 \mathrm{~A}, \mathrm{~B}$ ). There was no significant difference between the groups in fecal water content (Figure 3C).

\section{Effects of Salecan on the SIT}

After loperamide or clonidine administration, the SIT were significantly inhibited (Figure 4). The treatment with Salecan increased the SIT in a dose dependent manner in both loperamide- and clonidine-induced constipation model mice (Figure 4).

\section{Discussion}

Constipation is a highly prevalent functional gastrointestinal disorder, affecting the quality of life in constipated persons [7], and the use of dietary fiber in the prevention and treatment of constipation is a common practice in many countries of the world [16,28]. The present study has evaluated laxative effects of Salecan on normal as well as on loperamide- and clonidine-induced constipation mice.

As an agent for functional bowel disorders like diarrhea, loperamide used as constipation inducer is well documented. The drug inhibits intestinal fluid secretion and intestinal motility, leading to delay fecal evacuation time and intestinal luminal transit [29], and is used to induce a model of spastic constipation. On the other hand, clonidine also has a potent antidiarrheal effect, and has a suppressive effect on gastrointestinal contractions [30]. This drug can cause a model of atonic constipation. The observed decrease in the number and weight of feces by the treatment with these two drugs indicated induction of constipation in mice. Similar observation was reported by Kakino et al. [27].

Salecan is an identified extracellular macromolecule from Agrobacterium sp. ZX09, mainly composed of $\beta$ $(1 \rightarrow 3)$-D-glucosidic linkages as the main backbone structure, together with a small portion of $\alpha-(1 \rightarrow 3)-D$ glucosidic linkages [20]. Salecan is a non-toxic and watersoluble beta-glucan with excellent rheological properties $[21,23]$. Bacterial extracellular polysaccharides (e.g. dextran) can be easily produced and applied in food industry [31]. Beta-glucans are not digestible due to a lack of the hydrolase in gastrointestinal tract. Furthermore, Salecan increased fecal weight and fecal number in normal mice in present study. Similar observation was reported by Nakamura et al. [32] where brewer's yeast cell wall, which was composed mainly of polysaccharides, significantly increased fecal frequency and weight in normal rats. Due to these properties, it is presumed that Salecan has favorable effects on prevention of constipation.
The effects of Salecan on constipation in this study were tested in loperamide- and clonidine-induced constipation mice. The administration of Salecan to the constipated mice was effective in increasing the fecal number and fecal weight, which were indications of the laxative character of Salecan. Unlike clonidine, loperamide also markedly decreased the water content of feces through inhibition of intestinal fluid secretion. Treatment with Salecan significantly raised the fecal water content in loperamide-induced constipation mice. And the SIT time was shortened by the treatment with Salecan in both constipation models. The laxative effectiveness of dietary fibers, as bulk agents, depends on their WHC and swelling force [5]. Salecan was proved to have a high WHC. It may thus be concluded that the fecal output character was affected by the WHC and swelling force of Salecan in small intestine. This swelling force serves as a stimulus to defecation. Xu et al. [33] reported that supplementation of the diet with partially defatted flaxseed meal markedly decreased gastrointestinal transit time as well as increased fecal frequency and weight in constipated mice, which was dependent on luminal bulk. In addition, given the fact that soluble fibers may delay nutrients digestion and absorption by absorbing large quantities of water and forming gels in the gastrointestinal tract [34], Salecan might be possible to prevent the absorption of loperamide and clonidine in this results.

\section{Conclusion}

Our results demonstrate that Salecan, as a new structural glucan, alleviates the symptom of loperamide- and clonidineinduced constipation. Because of its easy availability, Salecan could be recommended as a cost-effective alternative for constipation.

\section{Abbreviations}

SIT: Small intestinal transit; WHC: Water holding capacity.

\section{Competing interests}

The authors declared no conflict of interest.

\section{Authors' contributions}

MYZ substantially contributed to study conception and design, as well as acquisition, analysis, and interpretation of data, drafting and revision of the manuscript. PJ and YBZ participated in the acquisition and analysis of data. AHX conceived of the study conception and design. JPC and YZ was involved in the experiments. PC helped to draft and revise the manuscript. JFZ contributed to study design, drafting and revision of the manuscript, and acquisition of funding. All authors read and approved the final manuscript.

\section{Acknowledgements}

This work was supported by grant from 973 Program 2012CB517505, JSSTP BE2011836 and FRFCU 2011XQTR07.

Received: 17 November 2012 Accepted: 14 March 2013

Published: 20 March 2013

\section{References}

1. Higgins PDR, Johanson JF: Epidemiology of constipation in North America: a systematic review. Am J Gastroenterol 2004, 99(4):750-759. 
2. Peppas G, Alexiou VG, Mourtzoukou E, Falagas ME: Epidemiology of constipation in Europe and Oceania: a systematic review. BMC Gastroenterol 2008, 8(1):5.

3. Stewart WF, Liberman JN, Sandler RS, Woods MS, Stemhagen A, Chee E, Lipton RB, Farup CE: Epidemiology of constipation (EPOC) study in the United States: relation of clinical subtypes to sociodemographic features. Am J Gastroenterol 1999, 94(12):3530-3540.

4. Wald A, Scarpignato C, Kamm M, MUELLER--LISSNER S, Helfrich I, Schuijt C, Bubeck J, Limoni C, Petrini O: The burden of constipation on quality of life: results of a multinational survey. Aliment Pharm Therap 2007, 26(2):227-236

5. Schiller L: The therapy of constipation. Aliment Pharm Therap 2001 15(6):749-763

6. Tack J: Current and future therapies for chronic constipation. Best Pract Res Cl Ga 2011, 25(1):151-158.

7. Ramkumar D, Rao SSC: Efficacy and safety of traditional medical therapies for chronic constipation: systematic review. Am J Gastroenterol 2005, 100(4):936-971.

8. Wood P, Weisz J, Blackwell B: Molecular characterization of cereal $\beta$-D-glucans. Structural analysis of oat $\beta$-D-glucan and rapid structural evaluation of $\beta$-D-glucans from different sources by high-performance liquid chromatography of oligosaccharides released by lichenase. Cereal Chem 1991, 68(1):31-39.

9. Manners DJ, Masson AJ, Patterson JC: The structure of a $\beta-(1 \rightarrow 3)-d-$ glucan from yeast cell walls. Biochem J 1973, 135(1):19.

10. Lazaridou A, Biliaderis C: Molecular aspects of cereal $\beta$-glucan functionality: physical properties, technological applications and physiological effects. J Cereal Sci 2007, 46(2):101-118.

11. Wong JMW, de Souza R, Kendall CWC, Emam A, Jenkins DJA: Colonic health: fermentation and short chain fatty acids. J Clin Gastroenterol 2006, 40(3):235.

12. Chang CF, Su MS, Chen HY, Liao I: Dietary beta-1, 3-glucan effectively improves immunity and survival of Penaeus monodon challenged with white spot syndrome virus. Fish Shellfish Immun 2003, 15(4):297-310.

13. López N, Cuzon G, Gaxiola G, Taboada G, Valenzuela M, Pascual C, Sánchez A, Rosas C: Physiological, nutritional, and immunological role of dietary $\beta$ 1-3 glucan and ascorbic acid 2-monophosphate in Litopenaeus vannamei juveniles. Aquaculture 2003, 224(1-4):223-243.

14. Snart J, Bibiloni R, Grayson T, Lay C, Zhang H, Allison GE, Laverdiere JK, Temelli F, Vasanthan T, Bell R: Supplementation of the diet with highviscosity beta-glucan results in enrichment for lactobacilli in the rat cecum. App Environ Microb 2006, 72(3):1925.

15. Chan G, Chan WK, Sze D: The effects of beta-glucan on human immune and cancer cells. J Hematol Oncol 2009, 2:25.

16. Anderson JW, Baird P, Davis RH Jr, Ferreri S, Knudtson M, Koraym A, Waters V, Williams CL: Health benefits of dietary fiber. Nutr Rev 2009, 67(4):188-205

17. Cummings $\mathrm{JH}$ : The Effect of Dietary Fiber on Fecal Weight and Composition. In CRC Handbook of Dietary Fiber in Human Nutrition. Thirdth edition. Edited by Spiller GA. Boca Raton, FL: CRC Press; 2001:183-252.

18. McRorie J, Daggy B, Morel J, Diersing P, Miner P, Robinson M: Psyllium is superior to docusate sodium for treatment of chronic constipation. Aliment Pharm Therap 1998, 12(5):491.

19. Brandt $L$, Prather CM, Quigley EMM, Schiller LR, Schoenfeld P, Talley NJ: Systematic review on the management of chronic constipation in North America. Am J Gastroenterol 2005, 100:S5-S21.

20. Xiu A, Kong Y, Zhou M, Zhu B, Wang S, Zhang J: The chemical and digestive properties of a soluble glucan from Agrobacterium sp. ZX09. Carbohyd Polym 2010, 82(3):623-628.

21. Xiu A, Zhan Y, Zhou M, Zhu B, Wang S, Jia A, Dong W, Cai C, Zhang J: Results of a 90-day safety assessment study in mice fed a glucan produced by Agrobacterium sp. ZX09. Food Chem Toxicol 2011, 49:2377-2384

22. Zhang $Y$, Xia L, Pang W, Wang T, Chen P, Zhu B, Zhang J: A novel soluble $\beta$-1, 3-d-glucan Salecan reduces adiposity and improves glucose tolerance in high-fat diet-fed mice. Brit J Nutr 2012, 1(1):1-9.

23. Xiu A, Zhou M, Zhu B, Wang S, Zhang J: Rheological properties of Salecan as a new source of thickening agent. Food Hydrocolloid 2011, 25:1719-1725

24. Maeda H, Zhu X, Mitsuoka T: Effects of an Exopolysaccharide (Kefiran) from Lactobacillus kefiranofaciens on Blood Glucose in KKAy Mice and
Constipation in SD Rats Induced by a Low-Fiber Diet. Biosci Microflora 2004, 23(4):149-153.

25. Shan J, Zhang Y, Diao Y, Qu W, Zhao X: Effect of an antidiabetic polysaccharide from Inula japonica on constipation in normal and two models of experimental constipated mice. Phytother Res 2010, 24(11):1734-1738.

26. Kakino M, Izuta H, Ito T, Tsuruma K, Araki Y, Shimazawa M, Oyama M, linuma $M$, Hara $\mathrm{H}$ : Agarwood induced laxative effects via acetylcholine receptors on loperamide-induced constipation in mice. Biosci Biotech Bioch 2010, 74(8):1550-1555.

27. Kakino M, Izuta H, Tsuruma K, Araki Y, Shimazawa M, Ichihara K, Hara H: Laxative effects and mechanism of action of Brazilian green propolis. BMC Complem Altern M 2012, 12(1):192.

28. Maffei HVL, Vicentini AP: Prospective evaluation of dietary treatment in childhood constipation: high dietary fiber and wheat bran intake are associated with constipation amelioration. J Pediatr Gastr Nutr 2011, 52(1):55.

29. Holzer P: Opioid receptors in the gastrointestinal tract. Regul Peptides 2009, 155(1-3):11.

30. Kojima R, Doihara H, Nozawa K, Kawabata-Shoda E, Yokoyama T, Ito H: Characterization of two models of drug-induced constipation in mice and evaluation of mustard oil in these models. Pharmacology 2009, 84(4):227-233

31. Sutherland IW: Novel and established applications of microbial polysaccharides. Trends Biotechnol 1998, 16(1):41-46.

32. Nakamura $T$, Agata $K$, Mizutani M, lino H: Effects of brewer's yeast cell wall on constipation and defecation in experimentally constipated rats. Biosci Biotech Bioch 2001, 65(4):774-780.

33. Xu J, Zhou X, Chen C, Deng Q, Huang Q, Yang J, Yang N, Huang F: Laxative effects of partially defatted flaxseed meal on normal and experimental constipated mice. BMC Complem Altern M 2012, 12(1):14

34. Vuksan V, Panahi S, Lyon M, Rogovik AL, Jenkins AL, Leiter LA: Viscosity of fiber preloads affects food intake in adolescents. Nutr Metab Cardiovas 2009, 19(7):498-503.

doi:10.1186/1471-230X-13-52

Cite this article as: Zhou et al.: Laxative effects of Salecan on normal and two models of experimental constipated mice. BMC Gastroenterology 2013 13:52.

\section{Submit your next manuscript to BioMed Central and take full advantage of:}

- Convenient online submission

- Thorough peer review

- No space constraints or color figure charges

- Immediate publication on acceptance

- Inclusion in PubMed, CAS, Scopus and Google Scholar

- Research which is freely available for redistribution 